\title{
Long-Term Effects of Human Papillomavirus Vaccination in Clinical Trials and Real-World Data: A Systematic Review
}

\author{
Megumi Kurosawa $^{1}$, Masayuki Sekine ${ }^{1, *(\mathbb{D}}$, Manako Yamaguchi ${ }^{1}{ }^{(\mathbb{D}}$, Risa Kudo ${ }^{1}$, Sharon J. B. Hanley ${ }^{2}$, \\ Megumi Hara ${ }^{3}{ }^{(D}$, Sosuke Adachi ${ }^{1}$, Yutaka Ueda ${ }^{4}$ (D), Etsuko Miyagi ${ }^{5}$ (D), Sayaka Ikeda ${ }^{6}$, Asami Yagi 4 \\ and Takayuki Enomoto ${ }^{1}$
}

Citation: Kurosawa, M.; Sekine, M.; Yamaguchi, M.; Kudo, R.; Hanley,

S.J.B.; Hara, M.; Adachi, S.; Ueda, Y.;

Miyagi, E.; Ikeda, S.; et al. Long-Term Effects of Human Papillomavirus Vaccination in Clinical Trials and Real-World Data: A Systematic Review. Vaccines 2022, 10, 256. https://doi.org/10.3390/ vaccines 10020256

Academic Editor: Giuseppe La Torre

Received: 30 December 2021

Accepted: 4 February 2022

Published: 8 February 2022

Publisher's Note: MDPI stays neutral with regard to jurisdictional claims in published maps and institutional affiliations.

Copyright: (C) 2022 by the authors. Licensee MDPI, Basel, Switzerland. This article is an open access article distributed under the terms and conditions of the Creative Commons Attribution (CC BY) license (https:// creativecommons.org/licenses/by/ $4.0 /)$.
1 Department of Obstetrics and Gynecology, Niigata University Graduate School of Medical and Dental Sciences, Niigata 951-8520, Japan; m-kurosawa@med.niigata-u.ac.jp (M.K.); manako0131@med.niigata-u.ac.jp (M.Y.); pearpear@med.niigata-u.ac.jp (R.K.); sadachi@med.niigata-u.ac.jp (S.A.); enomoto@med.niigata-u.ac.jp (T.E.)

2 Center for Environmental and Health Sciences, Hokkaido University, Sapporo 060-8638, Japan; sjbh1810@med.hokudai.ac.jp

3 Department of Preventive Medicine, Faculty of Medicine, Saga University, Saga 849-8501, Japan; harameg@cc.saga-u.ac.jp

4 Departments of Obstetrics and Gynecology, Osaka University Graduate School of Medicine, Osaka 565-0871, Japan; y.ueda@gyne.med.osaka-u.ac.jp (Y.U.); a.yagi@gyne.med.osaka-u.ac.jp (A.Y.)

5 Department of Obstetrics and Gynecology, Yokohama City University School of Medicine, Yokohama 236-0004, Japan; emiyagi@yokohama-cu.ac.jp

6 Division of Surveillance and Policy Evaluation, Institute for Cancer Control, National Cancer Center, Tokyo 104-0045, Japan; sayakaikeda0201@gmail.com

* Correspondence: masa@med.niigata-u.ac.jp

\begin{abstract}
The preventive effect of HPV vaccines against anogenital and oropharyngeal cancers has been proven in both clinical trials and real-world data. We reviewed the published evidence about the long-term efficacy and effectiveness of the HPV vaccine in available papers of clinical trials and realworld data. As far as we searched, the longest period of preventive effect for the bivalent, 4-valent, and 9-valent vaccine were 11 years in the Costa Rica trial, 14 years in the FUTURE II, and 8 years in the LTFU extension study of V503-002 and the Scandinavian study, respectively. The sustained clinical effect during the observation period was longest for the 4 -valent vaccine. In real-world data, the longest observation period of the vaccine effectiveness was 12 years in an Australian study for the 4-valent vaccine. On the other hand, the longest period of long-term persistence of HPV vaccine-induced seropositivity was 14 years in FUTURE II for the 4 -valent vaccine. For the bivalent vaccine, additional long-term follow-up studies may not have been planned due to the launch of the 4-valent and 9-valent vaccines. In some studies of the 9-valent vaccine, the results have not yet been published because of the short observation period. The additional results are expected in the future. In a national immunization program, most girls and boys are inoculated with HPV vaccine by the time puberty begins; thus, it is important to monitor the vaccine effect at least until the sexually active period in their 20 s and 30 s.
\end{abstract}

Keywords: HPV vaccination; long-term effect; clinical trial; real-world data; seropositivity

\section{Introduction}

Human papillomavirus (HPV) is mainly transmitted through sexual activity. In fact, HPV sequences have also been identified in chorionic villi tissues from pregnant females and other districts of the reproductive tract $[1,2]$. HPV infection is the most common viral infection of the genital tract and persistent infection with high-risk HPV types (HR-HPV) can cause changes from normal cells to precancerous and cancerous lesions [3] in both men and women. It is estimated that about $80 \%$ of men and women become infected during their lifetime, and are usually cured by the host's immune system [4]. Due to persistent 
HPV infection, HPV DNA is integrated into the host DNA. As a result, the onco-proteins E6 and E7 are expressed, causing the degradation of p53 and pRb, respectively. This is followed by the alteration of many cellular processes such as DNA repair, angiogenesis, apoptosis, etc., which ultimately lead to carcinogenesis [4].

More than 200 types of HPV have been identified, which are classified into high-risk types (such as types 16, 18, 31, 33, 35, 39, 45, 51, 52, 56, 58, 59, 66, 68, 73, and 82) that are carcinogenic, and low-risk types (such as types 6, 11, 42, 43, and 44) that cause anogenital warts and benign tumors, such as condyloma acuminata. High-risk HPV types are thought to be responsible for $7-8 \%$ of human malignancies, including $96 \%$ of cervical cancers, $93 \%$ of anal cancers, $64 \%$ of vaginal cancers, $51 \%$ of vulvar cancers, $36 \%$ of penile cancers, and $63 \%$ of oropharyngeal cancers. Among them, the risk of carcinogenesis from type 16 and 18 infections is particularly high [5].

HPV is estimated to cause nearly 36,000 cases of cancer in men and women every year in the United States. HPV vaccination can prevent 33,000 of these cancers by preventing the infections that cause them [6]. Especially in the prevention of cervical cancer, many reports from clinical trials have shown that the preventive effect of HPV16/18 infection and the development of cervical precancerous lesions are close to $100 \%$ [7-16]. The preventive effect against invasive cervical cancer has also been clearly proven worldwide. A significant reduction in invasive cervical cancer was reported in Sweden in 2020, followed by Denmark and England in 2021 in real-world data [17-19].

The HPV vaccine has been available since 2006 and targets mainly adolescent girls [20]. Currently, a national immunization program with the HPV vaccine is conducted in more than 100 countries [21]., and most programs target mainly young adolescent girls [22]. However, since the risk of HPV infection persists throughout the period of sexual activity in women, it is important to confirm the long-term preventive effect of the HPV vaccine [23].

\section{Methods}

Three databases (PubMed, Google Scholar, and ClinicalTrials.gov) and references or related articles were used to review the efficacy and effectiveness of HPV vaccination. In the database, related articles were identified using the following search string: ("human papillomavirus vaccination" OR "HPV vaccination" OR "human papillomavirus vaccine" OR "HPV vaccine") AND ("efficacy" OR "effectiveness" OR "effect" OR "clinical trial"). Given the search results, we added the terms "long term", "follow up", "extension", and "antibody" to cover all relevant articles.

PubMed and Google Scholar literature searches yielded a total of 1751 records. In addition, we found 35 literatures listed in the package insert and 150 studies in ClinicalTrials.gov of the HPV vaccines. After that, we screened 1936 records at the abstract/title level for eligibility according to exclusion criteria. Subsequently, 108 records were screened in full-text. A total of 36 publications reported relevant data of long-term effects of HPV vaccination. For this review, 32 clinical trials and 4 observational studies were included (Figure 1). 


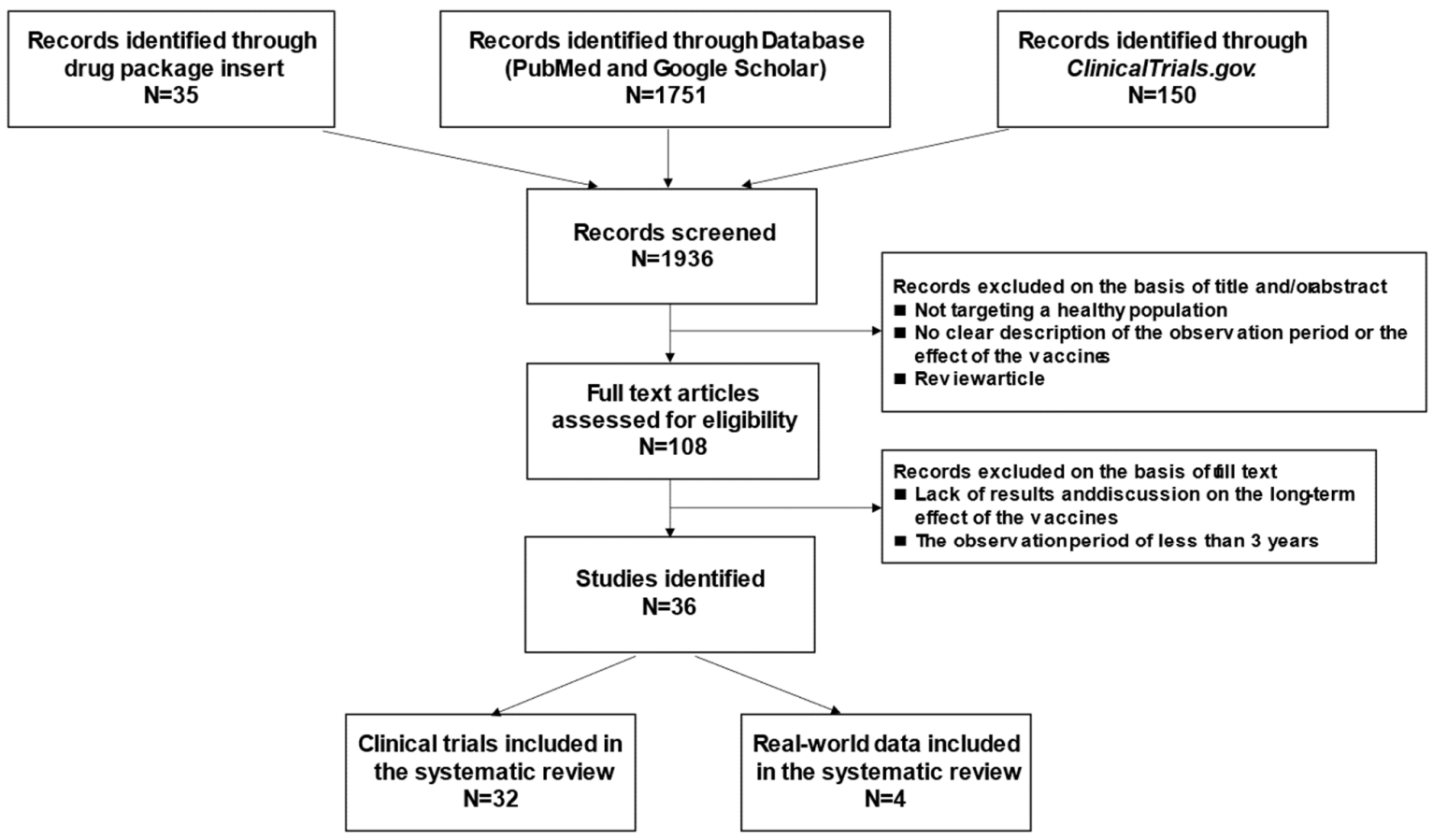

Figure 1. Flow-chart diagram of study selection. PubMed and Google Scholar literature searches yielded a total of 1751 records. In addition, we found 35 literatures listed in the package insert and 150 studies in ClinicalTrials.gov of the HPV vaccines. We screened 1936 records at the abstract/title level for eligibility according to exclusion criteria. Finally, 32 clinical trials and 4 observational studies were included for this review.

\section{Available Vaccines}

Currently, three types of HPV vaccines are used worldwide to prevent the development of cervical cancer. The bivalent vaccine (Cervarix ${ }^{\circledR}$ ) against HPV 16/18 (high-risk HPV type: HR-HPV), 4-valent vaccine (Gardasi ${ }^{\circledR}$ ) against HPV 6/11 (low-risk HPV type: LR-HPV) and HPV 16/18 (HR-HPV), and 9-valent vaccine (Gardasil $9^{\circledR}$ ) against HPV 6/11 (LR-HPV), and HPV 16/18/31/33/45/52 (HR-HPV) [24]. Cervarix ${ }^{\circledR}$ and Gardasil ${ }^{\circledR}$ could prevent $70 \%$ of cervical cancer cases, and Gardasil- $9^{\circledR}$ almost $90 \%$ [24]. Table 1 shows the vaccination schedule, dose, and adjuvant in each vaccine [25-27].

Table 1. Information of available HPV vaccines.

\begin{tabular}{|c|c|c|c|}
\hline & $\begin{array}{l}\text { Bivalent Vaccine } \\
\text { Cervarix }^{\circledR}\end{array}$ & $\begin{array}{l}\text { 4-Valent Vaccine } \\
\text { Gardasil }^{\circledR}\end{array}$ & $\begin{array}{l}\text { 9-Valent Vaccine } \\
\text { Gardasil9 }\end{array}$ \\
\hline $\begin{array}{l}\text { Target HPV } \\
\text { types }\end{array}$ & HPV 16/18 (HR-HPV) & $\begin{array}{l}\text { HPV 6/11 (LR-HPV) } \\
\text { HPV 16/18 (HR-HPV) }\end{array}$ & $\begin{array}{c}\text { HPV 6/11 (LR-HPV) } \\
\text { HPV 16/18/31/33/45/52 } \\
\text { (HR-HPV) }\end{array}$ \\
\hline Schedule & $\begin{array}{l}\text { Over } 10 \text { years } \\
0,1 \text {, and } 6 \text { months }\end{array}$ & $\begin{array}{c}\text { Over } 9 \text { years } \\
0,2 \text {, and } 6 \text { months }\end{array}$ & $\begin{array}{l}\text { Over } 9 \text { years } \\
0,2 \text {, and } 6 \text { months }\end{array}$ \\
\hline VLP dose & L1 dose $20 / 20 \mu \mathrm{g}$ & L1 dose 20/40/40/20 $\mu \mathrm{g}$ & $\begin{array}{l}\text { L1 dose } \\
30 / 30 / 60 / 40 / 20 / 20 / 20 / 20 / 20 \mu \mathrm{g}\end{array}$ \\
\hline Adjuvant & $\begin{array}{l}500 \mu \mathrm{g} \text { aluminum hydroxide, } \\
50 \mu \mathrm{g} \\
\text { 3-O-deacylated-4-monophosphoryl } \\
\text { lipid A }\end{array}$ & $\begin{array}{l}225 \mu \mathrm{g} \text { aluminum } \\
\text { hydroxyphosphate sulfate }\end{array}$ & $\begin{array}{l}500 \mu \mathrm{g} \text { aluminum } \\
\text { hydroxyphosphate sulfate }\end{array}$ \\
\hline
\end{tabular}

\section{Long-Term Efficacy: Clinical Trials}

Numerous clinical trials have been conducted to date for each vaccine. We considered the difference in efficacy depending on the vaccine used and target age (Tables 2-4). 
Table 2. Long-term effect on bivalent HPV vaccine.

\begin{tabular}{|c|c|c|c|c|c|}
\hline Study & $\begin{array}{l}\text { Study } \\
\text { Design }\end{array}$ & $\begin{array}{c}\text { Study } \\
\text { Subjects }\end{array}$ & Efficacy and Effectiveness & $\begin{array}{l}\text { Follow-Up } \\
\text { Period } \\
\text { (Seropositivity) }\end{array}$ & $\begin{array}{l}\text { Follow-Up } \\
\text { Period } \\
\text { (Clinical } \\
\text { Effect) }\end{array}$ \\
\hline HPV 001 [28] & Clinical trial & $\begin{array}{l}\text { Young women } \\
\text { (15-25 years) }\end{array}$ & $\begin{array}{l}\text { Reduced HPV } 16 / 18 \text { infection } \\
\text { and } \\
\text { HPV 16/18-related cytological } \\
\text { abnormalities }\end{array}$ & 3.6 years & 3.6 years \\
\hline HPV 032/063 [29] & Clinical trial & $\begin{array}{l}\text { Young women } \\
\text { (20-25 years) }\end{array}$ & $\begin{array}{c}\text { No case of } \\
\text { HPV16/18-associated CIN1+ }\end{array}$ & 4 years & 4 years \\
\hline $\begin{array}{c}\text { Extension } \\
\text { NCT00196937 [30] }\end{array}$ & Clinical trial & $\begin{array}{l}\text { Women } \\
\text { (15-55 years) }\end{array}$ & $\begin{array}{c}\text { Sustained anti-HPV-16/18 } \\
\text { seropositivity rates }\end{array}$ & 6 years & - \\
\hline HPV 007 [31] & Clinical trial & $\begin{array}{l}\text { Young women } \\
\text { (15-25 years) }\end{array}$ & $\begin{array}{c}\text { No case of persistent infection } \\
\text { or CIN2+ associated with } \\
\text { HPV-16/18 }\end{array}$ & 6.4 years & 6.4 years \\
\hline VIVIAN study [32] & Clinical trial & $\begin{array}{l}\text { Adult women } \\
\text { (> } 25 \text { years })\end{array}$ & $\begin{array}{c}\text { Reduced HPV } 16 / 18 \text { infection, } \\
\text { Cytological abnormalities and } \\
\text { CIN1+ }\end{array}$ & - & 7 years \\
\hline HPV 023 [33] & Clinical trial & $\begin{array}{l}\text { Young women } \\
\text { (15-25 years) }\end{array}$ & $\begin{array}{l}\text { No new infection or CIN2+ } \\
\text { associated with HPV 16/18 }\end{array}$ & 8.4 years & 8.4 years \\
\hline $\begin{array}{c}\text { Extension HPV023 } \\
{[34]}\end{array}$ & Clinical trial & $\begin{array}{l}\text { Young women } \\
\text { (15-25 years) }\end{array}$ & $\begin{array}{c}\text { No case of HPV16/18 } \\
\text { infection and } \\
\text { HPV16/18-related } \\
\text { Histropathological } \\
\text { abnormalities }\end{array}$ & 9.4 years & 9.4 years \\
\hline NCT 00947115 [35] & Clinical trial & $\begin{array}{c}\text { Women } \\
\text { (15-55 years) }\end{array}$ & $\begin{array}{l}\text { Sustained anti-HPV-16/18 } \\
\text { antibody titers }\end{array}$ & 10 years & - \\
\hline $\begin{array}{c}\text { Costa Rica Vaccine } \\
\text { Tria [36] }\end{array}$ & Clinical trial & $\begin{array}{l}\text { Young women } \\
\text { (18-25 years) }\end{array}$ & $\begin{array}{l}\text { Reduced HPV16/18-related } \\
\text { CIN2/3 }\end{array}$ & - & 11.1 years \\
\hline $\begin{array}{c}\text { P011-NCT } 00309166 \\
\text { [37] }\end{array}$ & Clinical trial & $\begin{array}{c}\text { Men } \\
\text { (10-18 years) }\end{array}$ & $\begin{array}{c}\text { Higher antibody titers of HPV } \\
16 / 18\end{array}$ & 7 months & 7 months \\
\hline Niigata Study [38] & $\begin{array}{l}\text { Real-world } \\
\text { data }\end{array}$ & $\begin{array}{l}\text { Young women } \\
\text { (25-26 years) }\end{array}$ & $\begin{array}{l}\text { Reduced HPV } 16 / 18 \text { and } \\
\text { HPV31/45/52 infection }\end{array}$ & - & 9 years \\
\hline
\end{tabular}

CIN, cervical intraepithelial neoplasia.

Table 3. Long-term effect on 4-valent vaccine.

\begin{tabular}{|c|c|c|c|c|c|}
\hline Study & $\begin{array}{l}\text { Study } \\
\text { Design }\end{array}$ & $\begin{array}{l}\text { Study } \\
\text { Subjects }\end{array}$ & Efficacy and Effectiveness & $\begin{array}{l}\text { Follow-Up } \\
\text { Period } \\
\text { (Seropositivity) }\end{array}$ & $\begin{array}{l}\text { Follow-Up Period } \\
\text { (Clinical Effect) }\end{array}$ \\
\hline FUTURE I [39] & Clinical trial & $\begin{array}{l}\text { Young women } \\
\text { (16-24 years) }\end{array}$ & $\begin{array}{l}\text { Reduced HPV-related } \\
\text { anogenital disease }\end{array}$ & 2 years & 3.6 years \\
\hline HPV P007 [40] & Clinical trial & $\begin{array}{l}\text { Young women } \\
\text { (16-23 years) }\end{array}$ & $\begin{array}{c}\text { No case of HPV } \\
\text { 6/11/16/18-related CIN }\end{array}$ & 5 years & 5 years \\
\hline $\begin{array}{c}\text { Extension P007 } \\
{[41]}\end{array}$ & Clinical trial & $\begin{array}{l}\text { Young women } \\
\text { (16-23 years) }\end{array}$ & $\begin{array}{l}\text { Sustained serum anti-HPV } \\
6 / 11 / 16 / 18 \text { immunoglobulin } \\
\text { levels }\end{array}$ & 5 years & - \\
\hline $\begin{array}{c}\text { Extension P019 } \\
\text { [42] }\end{array}$ & Clinical trial & $\begin{array}{l}\text { Adult women } \\
\text { ( } 24-45 \text { years) }\end{array}$ & $\begin{array}{c}\text { Reduced HPV } \\
\text { 6/11/16/18-related CIN }\end{array}$ & 6 years & 6 years \\
\hline Nordic P015 [43] & Clinical trial & $\begin{array}{l}\text { Young women } \\
\text { (16-23 years) }\end{array}$ & $\begin{array}{c}\text { No case of HPV } \\
6 / 11 / 16 / 18 \text {-related CIN }\end{array}$ & 9 years & 8 years \\
\hline P019-21 [26] & Clinical trial & $\begin{array}{l}\text { Adult women } \\
\text { ( } 24-45 \text { years) }\end{array}$ & $\begin{array}{c}\text { No case of HPV } \\
6 / 11 / 16 / 18 \text {-related CIN, AIS } \\
\text { and EGL }\end{array}$ & 10 years & 10 years \\
\hline V501-018-11 [44] & Clinical trial & $\begin{array}{l}\text { Girls and Boys } \\
\text { (9-15 years) }\end{array}$ & $\begin{array}{l}\text { No case breakthrough disease } \\
\text { in the form of genital warts or } \\
\text { cervical and/or genital } \\
\text { precancers and cancers }\end{array}$ & 10.5 years & 10 years \\
\hline
\end{tabular}


Table 3. Cont.

\begin{tabular}{|c|c|c|c|c|c|}
\hline Study & $\begin{array}{l}\text { Study } \\
\text { Design }\end{array}$ & $\begin{array}{c}\text { Study } \\
\text { Subjects }\end{array}$ & Efficacy and Effectiveness & $\begin{array}{l}\text { Follow-Up } \\
\text { Period } \\
\text { (Seropositivity) }\end{array}$ & $\begin{array}{l}\text { Follow-Up Period } \\
\text { (Clinical Effect) }\end{array}$ \\
\hline $\begin{array}{l}\text { FUTURE II } \\
\text { (P015-21) [45] }\end{array}$ & Clinical trial & $\begin{array}{l}\text { Young women } \\
\text { (16-23 years) }\end{array}$ & $\begin{array}{l}\text { No case of HPV16/18 related } \\
\text { CIN2+ and cervical cancer }\end{array}$ & 14 years & 14 years \\
\hline $\begin{array}{c}\text { P020-AIN } \\
\text { substudy }\end{array}$ & Clinical trial & Men-MSM & Reduced AIN (grade 2+) & - & 3 years \\
\hline $\begin{array}{l}\text { NCT00090285 [47] } \\
\text { (Extension } \\
\text { P020/P020-11) }\end{array}$ & Clinical trial & $\begin{array}{l}\text { Men (including } \\
\text { MSM) } \\
\text { (16-26 years) }\end{array}$ & $\begin{array}{c}\text { No case of HPV } \\
\text { 6/11/16/18-related EGL }\end{array}$ & - & $\begin{array}{c}9.5 \text { years in early } \\
\text { vaccination } \\
4.7 \text { years in } \\
\text { catch-up } \\
\text { vaccination }\end{array}$ \\
\hline P020-21 [48] & Clinical trial & $\begin{array}{c}\text { Men } \\
\text { (16-26 years) }\end{array}$ & $\begin{array}{c}\text { No case of HPV 6/11-related } \\
\text { genital warts, HPV } \\
\text { 6/11/16/18-related EGL or } \\
\text { AIN }\end{array}$ & 10 years & $\begin{array}{l}10 \text { years (up to } \\
11.5 \text { years) }\end{array}$ \\
\hline $\begin{array}{l}\text { Australian study } \\
\text { (2015) [49] }\end{array}$ & $\begin{array}{l}\text { Real-world } \\
\text { data }\end{array}$ & $\begin{array}{c}\text { Women } \\
(18-24, \\
25-35 \text { years })\end{array}$ & $\begin{array}{l}\text { Reduced vaccine-targeted } \\
\text { HPV infection }\end{array}$ & - & 9 years \\
\hline Danich study [50] & $\begin{array}{l}\text { Real-world } \\
\text { data }\end{array}$ & $\begin{array}{l}\text { Adult women } \\
\text { (born in 1993, } \\
1983 \text { ) }\end{array}$ & Reduced high-grade CIN & - & 10 years \\
\hline $\begin{array}{l}\text { Australian study } \\
\quad \text { (2020) }[51]\end{array}$ & $\begin{array}{l}\text { Real-world } \\
\text { data }\end{array}$ & $\begin{array}{c}\text { Women } \\
\text { (18-35 years) }\end{array}$ & $\begin{array}{c}\text { Reduced vaccine-targeted } \\
\text { HPV infection }\end{array}$ & - & 12 years \\
\hline
\end{tabular}

Table 4. Long-term effect on 9-valent vaccine.

\begin{tabular}{|c|c|c|c|c|c|}
\hline Study & $\begin{array}{l}\text { Study } \\
\text { Design }\end{array}$ & Study Subjects & Efficacy and Effectiveness & $\begin{array}{l}\text { Follow-Up } \\
\quad \text { Period } \\
\text { (Seropositivity) }\end{array}$ & $\begin{array}{l}\text { Follow-Up } \\
\text { Period } \\
\text { (Clinical } \\
\text { Effect) }\end{array}$ \\
\hline $\begin{array}{c}\text { Latin American } \\
\text { study [52] }\end{array}$ & Clinical trial & $\begin{array}{l}\text { Young women } \\
\text { (16-26 years) } \\
\text { and girls and } \\
\text { boys (9-15 years) }\end{array}$ & $\begin{array}{c}\text { Prevented } \\
\text { HPV31/33/45/52/58-related } \\
\text { high-grade cervical, vulvar and } \\
\text { vaginal dysplasia }\end{array}$ & 5 years & 5 years \\
\hline $\begin{array}{c}\text { Extension } \\
\text { V503-001 [53] }\end{array}$ & Clinical trial & $\begin{array}{l}\text { Young women } \\
\text { (16-26 years) }\end{array}$ & $\begin{array}{c}\text { Prevented persistent } \\
\text { vaccine-targeted HPV infection, } \\
\text { cytological abnormalities, } \\
\text { high-grade lesions, and cervical } \\
\text { procedures }\end{array}$ & 5 years & 6 years \\
\hline $\begin{array}{c}\text { LTFU extension } \\
\text { study of V503-002 } \\
{[54]}\end{array}$ & Clinical trial & $\begin{array}{l}\text { Girls and boys } \\
\text { (9-15 years) }\end{array}$ & $\begin{array}{l}\text { No case of vaccine-targeted HPV } \\
\text { infection, or } \\
\text { high-grade CIN, AIS, VIN, VaIN, } \\
\text { PIN, or genital warts }\end{array}$ & 7 years & 8 years \\
\hline $\begin{array}{l}\text { Scandinavian } \\
\text { study [55] }\end{array}$ & Clinical trial & $\begin{array}{l}\text { Young women } \\
\text { (16-26 years) }\end{array}$ & $\begin{array}{c}\text { No case of HPV } \\
\text { 16/18/31/33/45/52/58-related } \\
\text { high-grade CIN }\end{array}$ & - & 8 years \\
\hline
\end{tabular}

CIN; cervical intraepithelial neoplasia; AIS, adenocarcinoma in situ; VIN, vulvar intraepithelial neoplasia; VaIN, vaginal intraepithelial neoplasia; PIN, penile intraepithelial neoplasia.

\subsection{Bivalent Vaccine}

\subsubsection{Young Women}

According to a previous review on the long-term effect on precancers [23], the observation period for the bivalent HPV vaccine was 3.6 years in the HPV 001 [25], 6.4 years in the HPV 007 [34], 8.4 years in the HPV 023 [56], and 9.4 years in the Extension HPV023 
trial [34]. In the current situation, the longest follow-up period for bivalent vaccines to date is 11.1 years in the Costa Rica Vaccine Trial [36]. Extension NCT00196937 [37] and NCT 00947115 [35] were clinical trials of evaluations for long-term immunogenicity.

The extension HPV023 trial on a bivalent vaccine was an initial double-blind, randomized, placebo-controlled study in women aged 15-25 years with normal pre-vaccination cytology [34]. As a result, no HPV16/18-associated infections or cyto-histopathological abnormalities occurred in the vaccine group 9.4 years after vaccination. The results showed that no HPV16/18-related infections or pathological abnormalities occurred 9.4 years after vaccination in the vaccine group. Vaccine efficacy (VE) was 100\% against HPV-16/18 infection, $95.0 \%$ against low grade squamous intraepithelial lesion (LSIL)+, 100\% against cervical intraepithelial neoplasia (CIN)1+, and 100\% against CIN2+ associated with HPV16/18

In the Costa Rica Vaccine Trial, a randomized, double-blind, controlled trial that assessed the efficacy of the initial bivalent vaccination, women aged 18-25 years were enrolled. As a result, cumulative VE against HPV 16/18-associated CIN2+ (CIN2 or worse) and CIN3+ (CIN3 or worse) over the 11.1-year period was 97.4\% (95\% confidence interval [CI], 88.0-99.6) and 94.9\% (73.7-99.4), respectively [36]. This report shows the longest efficacy period of a bivalent vaccine.

\subsubsection{Adult Women}

The longest follow-up period so far was 7 years in the VIVIANE study. In the VIVIANE study, a 7-year follow-up of a double-blind, randomized controlled study involving women age $>25$ years; women were randomly assigned (1:1) to receive a bivalent vaccine or aluminum hydroxide control, using an internet-based system. In addition, 4407 women were assigned to a cohort following the protocol for efficacy (vaccinated, $\mathrm{n}=2209$; controls, $n=2198$ ) and 5747 women were assigned to the total vaccination cohort (vaccinated, $n=2877$; controls, $n=2870$ ). The vaccine showed efficacy in preventing persistent HPV16/18 infection, cytological abnormalities, and CIN1+ [32].

\subsubsection{Men}

The P011-NCT00309166 trial was the first to investigate the efficacy of the bivalent vaccine in boys [37]. In this study, healthy boys aged 10-18 years were randomized (2:1 ratio) to receive the vaccine $(n=181)$ or hepatitis B virus (HBV) control vaccine $(n=89)$ at 0,1 , and 6 months, and were followed for 7 months. The antibody titers of HPV 16/18 in men aged 10-18 and 10-14 years at 7 months after vaccination were higher than those in women aged 15-25 and 10-14 years in previous reports [57].

\subsection{4-Valent Vaccine}

\subsubsection{Young Women}

The observation period was 3.6 years in the FUTURE I [39], 5 years in the HPVP007 [39], 8 years in the Nordic P015 [43], 10 years in the V501-018-11 [44], and 14 years in the FUTURE II [45].

In the V501-018-11 trial on men and women aged 9-15 years, during the 10-year follow-up period no genital warts, cervical and/or genital pre-cancers or cancers were observed [44].

Recently, a final report of the FUTURE II on a 4-valent vaccine was published [45]. In the randomized, double-blind, placebo-controlled study in Northern Europe, women aged 16-23 years received three doses of the 4-valent vaccine and were followed up for an additional $\geq 10$ years. No cases of high-grade cervical dysplasia associated with HPV16/18 were observed in the protocol validated population $(n=2121)$ during the entire study period. VE of $100 \%$ (95\% CI, 94.7-100) was demonstrated at 12 years or more, with a trend toward sustained protection up to 14 years after vaccination. 


\subsubsection{Adult Women}

The longest follow-up period so far was 10 years in the P019-21 trial [26]. The P019 trial evaluated the efficacy of the 4-valent vaccine in women aged 24-45 years [58]. In this study, 3919 women aged 24-45 years, with no history of cervical disease or genital warts in the past 5 years, were enrolled. The 4 -valent vaccine or placebo was given on day 1 and, after 2 and 6 months. This study showed the efficacy of the 4-valent vaccine in the prevention of HPV 6/11 (LR-HPV) and HPV 16/18 (HR-HPV) infection, CIN, and external genital lesions (EGL) related to HPV 6/11/16/18 for 4 years. In the Extension P019 and the P019-21 trials, there were no cases of HPV 6/11/16/18-related CIN, AIS and EGL during the 6-10 year extended follow-up [26,42].

\subsubsection{Men}

Several extension studies of V501-P020 [59,60] were reported previously (P020-AIN substudy [46], NCT00090285 [59] and P020-21 [48]). The longest follow-up period was 10 years (up to 11.5 years) in P020-21 [26,48].

NCT00090285 trial [47] is an open-label, long-term follow-up extension multicentre study conducted at 46 centers in 16 countries. After the P020 and P020-11 trial [46,59], participants who had received at least one dose of the 4-valent HPV vaccine in the previous study were defined as the early vaccination group. Placebo recipients in the previous trial were offered three doses of 4-valent HPV vaccine at the end of the trial, and those who received one or more doses were enrolled in the long-term follow-up (LTFU) trial as the catch-up vaccination group. The early vaccination group was followed for a median of 9.5 years (range, 0.1-11.5) after receiving the third dose of the vaccine, and the catch-up vaccination group was followed for a median of 4.7 years (0.0-6.6) after receiving the third dose. In both groups, there were no new reported cases of HPV 6/11 (LR-HPV) and HPV 16/18 (HR-HPV)-related EGL and there was a lower incidence of HPV 6/11/16/18-related anal intraepithelial neoplasia and anal cancer.

In P020-21, a follow-up study of V501-P020, a preventive effect against HPV 6/11/16/18related anal cancer and its precursor lesion, condyloma acuminata, was observed for up to 11.5 years after the third inoculation [48]. The V501-P020 trial, a randomized, placebocontrolled, double-blind trial, examined the efficacy of the 4-valent vaccine in preventing infection and genital disease in men $[59,60]$. In the trial, 4065 healthy men aged 16-26 years from 18 countries were enrolled and observed for 3 years. Eligible participants were heterosexual men aged 16-23 years or men who had sex with men aged 16-26 years.

Furthermore, in the V501-018-11 trial for men and women aged 9-15 years, no breakthrough disease in the forms of genital warts or cervical and/or genital precancers and cancers were observed in the 10-year follow-up period [44].

\subsection{9-Valent Vaccine}

\subsubsection{Young Women}

The observation periods for the 9-valent vaccine was 5 years in a Latin American study [52], 6 years in the extension V503-001 [53], 8 years in a Scandinavian study [55] and 8 years in the LTFU extension study [54].

The Latin American study included a randomized, double-blind, controlled trial in women aged 16-26 years and an immunogenicity study in girls and boys aged 9-15 years [52]. The 9-valent vaccine prevented HPV 31/33/45/52/58-related high-grade cervical, vulvar, and vaginal dysplasia with $92.3 \%$ effectiveness (95\% CI, 54.4-99.6). Antibody responses to the 9-valent HPV vaccine types persisted for more than 5 years.

The V503-001 trial was a randomized, international, multicenter, double-blind study in women aged 16-26 years [61]. In the study, 14,215 participants randomly received the 9 -valent vaccine or the 4-valent vaccine on day 1 and at 2 and 6 months. The results showed that the 9-valent vaccine prevented approximately $97 \%$ of high-grade cervical, vulvar, and vaginal diseases associated with HPV 31/33/45/52/58, and the increase in antibody titer against HPV 6/11 (LR-HPV) and HPV 16/18 (HR-HPV) was not inferior to that of the 
4-valent vaccine. In the extension V503-001 study, the 9-valent vaccine prevented persistent HPV infection, cytological abnormalities, high-grade lesions, and cervical procedures related to the HPV types covered by the vaccine for up to 6 years [53].

In the LTFU extension study of V503-002 [55,56], the 9-valent vaccine elicited HPV antibodies that persisted for at least 7 years after three doses of the vaccine in girls and boys aged 9-15 years of age [54]. Approximately 8 years after vaccination, there were no cases of high-grade CIN, adenocarcinoma-in-situ, vulvar intraepithelial neoplasia, vaginal intraepithelial neoplasia, or genital warts related to the 9-valent vaccine types in women.

In the Scandinavian study, 1448 women aged 16-26 years were followed for the development of HPV16/18/31/33/45/52/58-related high-grade cervical dysplasia [55]. The results suggested that the 9 -valent vaccine provides statistically significant protection for at least 6 years and remains effective for 8 years.

\subsubsection{Adult Women}

To the best of our knowledge, there are no reports on the long-term effects of the 9 -valent vaccine in adult women.

\subsubsection{Men}

In the LTFU extension study of V503-002 [62,63], in approximately 8 years after vaccination, there were no cases of penile intraepithelial neoplasia (PIN) or genital warts in men related to the 9-valent vaccine types [54].

\section{Long-Term Effectiveness: Real-World Data}

There are several reports on bivalent and 4-valent vaccines (Tables 2 and 3).

\subsection{Young Women}

The observation period of long-term effectiveness for the 4-valent vaccine was 9 years in an Australian study (2015) [49], 10 years in a Danish study [50] and 12 years in another Australian study (2020) [51].

The Australian study (2015) [49] compared HR-HPV prevalence in women aged 18-24 and 25-35 years between the vaccinated and pre-vaccine introduction generations. The results showed that the prevalence of vaccine-targeted HPV types was significantly reduced in the young women 9 years after vaccination.

In the Danish study [50], 19,951 women born in 1993 who received the publicly funded 4-valent HPV vaccine at age 15 (vaccination coverage: 91\%) and 15,748 women born in 1983 who were not eligible for publicly funded vaccination (vaccination coverage: $<0.1 \%$ ) were followed for 10 years from age 15 to 25 years of age. The results showed that the relative risk of developing CIN2+ and CIN3+ was significantly lower in women born in 1993 (CIN2+: RR $=0.74$ 95\% CI 0.66-0.82, CIN3+: RR 0.68 95\% CI 0.58-0.79).

The Australian study (2020) [51] investigated the effectiveness of the 4-valent vaccine on HPV infection in 1564 women aged 18-35 years (median 24 years). The HPV infection rate of the vaccine target HPV types was $0.7 \%$ in the vaccinated group, which was significantly lower than the $5.5 \%$ in the unvaccinated group (OR 0.13 95\% CI $0.05-0.30$ ) 9-12 years after the vaccine program introduction.

Recently, the long-term 9-year effectiveness of the bivalent vaccine against HPV16/18 and 31/45/52 infection was reported in Japanese women aged 25-26 years [38]. HPV16/18 infection rate was $0 \%(0 / 150)$ in the vaccinated group and $5.4 \%(15 / 279)$ in the unvaccinated group, showing a significant difference $(p=0.0018)$, and the vaccine effectiveness was $100 \%$. Cross-protective-type HPV31/45/52 infection rate in the vaccinated group was significantly lower than that in the unvaccinated group $(3.3 \%$ vs. $10.0 \%: p=0.013)$.

\subsection{Adult Women}

In the Australian study (2015), the 4-valent HPV vaccination program targeting girls aged 12-13 years commenced in 2007, with catch-up vaccination of women aged 
14-26 years through 2009. In the study, HPV prevalence in women aged 18-24 and 25-35 years in 2015 was compared with that in 2005-2007 [49]. The results showed that the prevalence of the 4-valent HPV vaccine types decreased from $11.8 \%$ (2005-2007) to $1.1 \%$ (2015) among women aged 25-35 years $(p=0.001)$, and its effectiveness was confirmed 9 years after vaccination. The authors stated that despite the low vaccination rate of $40.3 \%$ among women aged 25-35 years, the significant reduction in HPV prevalence may be due to the effect of strong herd protection.

\section{Long-Term Persistence of HPV Vaccine-Induced Seropositivity}

\subsection{Bivalent Vaccine}

The observation period of long-term persistence of HPV vaccine-induced seropositivity for the bivalent vaccine was 4 years in HPV 032/063 [64], 6 years in Extension NCT00196937 [56], 9.4 years in HPV001/007/023/Extension HPV023 [34], and 10 years in NCT 00,947,115 trial [35].

In the HPV-001 [28], 007 [34], and 023 [33] trials for women aged 15-25 years, the geometric mean titer (GMT) for HPV 16/18 peaked 7 months after the first inoculation and was maintained for 9.4 years (113 months). At that time, GMT was more than 10 times the antibody titer due to natural infection in both HPV 16/18 types [25], and the antibody positive rate was maintained at 100\% [34] in the Extension 023 trial.

The P014 trial [29] and its follow-up study (NCT00196937) [30] evaluated the persistence of antibody titers in women aged $15-55$ years who received their first vaccination. The study showed that GMTs for HPV 16/18 at 18 months after the first inoculation were in the same range as the plateau GMTs in the HPV-001 and 007 studies. Furthermore, although the GMTs were slightly lower in the age group of 26-55 years than in the age group of 15-25 years, the antibody titer after 48 months was maintained at a higher level than that after natural infection. The antibody titer was maintained for 6 and 10 years after the first inoculation in Extension NCT00196937 [56] and NCT00947115 [35], respectively.

In healthy boys, the P011-NCT00309166 trial examined the efficacy of the bivalent vaccine in healthy boys [37]. The antibody titers of HPV 16/18 in boys aged 10-18 and 10-14 years at 7 months after vaccination were higher than those in women aged 15-25 and $10-14$ years in previous studies [57].

\subsection{4-Valent Vaccine}

The longest period of long-term persistence of HPV vaccine-induced seropositivity for the 4-valent vaccine was 14 years in FUTURE II [45] (P015-21) for women, and 10-10.5 years in the P020-21 [48] and V501-018-11 [44] trials for men.

In the final report of the P015-21 (follow-up study of the P015 FUTURE II) in women aged 16-26 years, the antibody positivity rates of HPV 6/11 (LR-HPV) and HPV 16/18 (HR-HPV) were $90.6 \%, 91.1 \%, 98.3 \%$, and $52.4 \%$ at 14 years after the first inoculation, respectively [45].

In the P020 trial for men aged 16-26 years, the antibody positivity rates for HPV $6 / 11 / 16 / 18$ after 3 years were $86.9 \%, 78.0 \%, 92.3 \%$, and 60.7\%, respectively [59]. Furthermore, in the follow-up study (P020-21), the antibody positivity rates for HPV 6/11/16/18 were $79.1 \%, 79.9 \%, 94.9 \%$, and $40.2 \%$ at 10 years after inoculation, respectively [ 48 ].

The V501-018-11 [44] trial was conducted on boys and girls aged 9-15 years, and the antibody positivity rates for HPV 6/11/16/18 at 10.5 years after the first inoculation were $86.6 \%, 87.2 \%, 94.1 \%$ and $59.6 \%$ in boys, respectively. In contrast, the antibody positivity rates were $91.0 \%, 90.1 \%, 97.7 \%$, and $61.4 \%$ in girls, respectively. There seems to be no difference in HPV antibody titers between boys and girls.

\subsection{9-Valent Vaccine}

The longest period of long-term persistence of HPV vaccine-induced seropositivity for the 9-valent vaccine was 5 years in Extension V503-001 [53] and the Latin American 
study [52] for young women, and 7 years in the LTFU extension study of V503-002 [54] for girls and boys.

The V503-001 trial confirmed that the antibody response against the 9-valent HPV vaccine type persisted for at least 5 years in women aged 16-26 years, and the antibody positivity rate was ranged from $78 \%$ to $100 \%$ at 5 years after the third inoculation $[53,65]$. In the V503-002 trial in girls and boys aged 9-15 years, it was confirmed that the antibody response lasted for at least 5 years after three doses of the 9 -valent vaccine $[62,63]$, and the antibody positivity rate against HPV 6/11 (LR-HPV) and HPV 16/18/31/33/45/52/58 (HR-HPV) ranged from $90 \%$ to $99 \%$ at 5 years after inoculation [62].

A Latin American study [52] confirmed that the antibody titer of the 9-valent vaccine was sustained for 5 years in boys aged 9-15 years.

In the LTFU extension study [54], three doses of the 9-valent vaccine induced HPV antibodies that persisted for at least 7 years in girls and boys aged 9-15 years. GMTs reached its peak at 7 months ( 1 month after three doses), then declined sharply at 12 months, followed by a slower decrease between 24 and 90 months. Most participants remained seropositive for each 9-valent HPV vaccine type at the last immunogenicity assessment. GMTs at 90 months in the participants were equal to or higher than the GMT at 60 months for women who received the 9-valent vaccine in a previous study [53].

\section{Conclusions}

HPV is mainly transmitted through sexual activity and causes infections that can lead to HPV-associated cancers in both men and women. The preventive effect of HPV vaccines against anogenital and oropharyngeal cancers has been proven in both clinical trials and real-world data. The longest periods of preventive effect for the bivalent, 4-valent, and 9-valent vaccines were 11 years in the Costa Rica trial [36], 14 years in the FUTURE II [45], and 8 years in the LTFU extension study of V503-002 [54] and the Scandinavian study [55], respectively. The sustained clinical effect during the observation period was longest for the 4-valent vaccine. In real-world data, the longest observation period of the vaccine effectiveness was 12 years in an Australian study [51] for the 4-valent vaccine. On the other hand, the longest period of long-term persistence of the HPV vaccine-induced seropositivity for the 4-valent vaccine was 14 years in FUTURE II.

Regarding the bivalent vaccine, it is possible that research on the long-term follow-up trial was not planed due to the launch of the 4-valent and 9-valent vaccines. In some studies of the 9-valent vaccine, the results have not yet been published because of the short observation period [54,55]. The results are expected in the future.

In this review, antibody titers were also mentioned. However, the correlation between the immunological efficacy of antibodies and the clinical efficacy of HPV infection prevention has not yet been established, and it has not been confirmed whether the preventive effect of the vaccine is due to sustained antibody titers. In addition, there is still no consensus on the minimum amount of antibodies needed to prevent HPV infection.

In a national immunization program, most girls and boys are inoculated with HPV vaccine by the time puberty begins; thus, it is important to monitor the vaccine effect at least until the sexually active period in their 20 s and 30 s.

Author Contributions: Conceptualization, M.S., Y.U., A.Y., S.A., E.M., S.I. and T.E.; Project administration, M.S.; Literature search, M.K., R.K., and M.Y.; Writing-original draft, M.K. and M.S.; Writing-review and editing, M.S., M.H. and S.J.B.H.; Funding acquisition and supervision, T.E. All authors have read and agreed to the published version of the manuscript.

Funding: This work was supported by the Japanese Agency for Medical Research and Development (JP21ck0106562).

Institutional Review Board Statement: Not applicable.

Informed Consent Statement: Not applicable.

Data Availability Statement: Not applicable. 
Conflicts of Interest: M.Y. received lecture fees from Merck Sharp and Dohme. T.E. received lecture fees from Merck Sharp and Dohme. Y.U. received lecture fees from Glax-oSmithKline/Japan Vaccine and Merck Sharp and Dohme, as well as research funds from Merck Sharp and Dohme. E.M. received honoraria and lecture fees from Roche Diagnostics and Merck Sharp and Dohme, as well as grants from Merck Sharp and Dohme. M.H. received lecture fees from GlaxoSmithKlineJapanVaccine, Merck Sharp and Dohme, and Sanofi Pasteur Inc. All other authors report no potential conflicts.

\section{References}

1. Tognon, M.; Tagliapietra, A.; Magagnoli, F.; Mazziotta, C.; Otòn-Gonzalez, L.; Lanzillotti, C.; Vesce, F.; Contini, C.; Rotondo, J.C.; Martini, F. Investigation on spontaneous abortion and human papillomavirus infection. Vaccines 2020, 8, 473. [CrossRef]

2. Sarkola, M.E.; Grénman, S.E.; Rintala, M.A.; Syrjänen, K.J.; Syrjänen, S.M. Human papillomavirus in the placenta and umbilical cord blood. Acta Obs. Gynecol Scand. 2008, 87, 1181-1188. [CrossRef]

3. Dilley, S.; Miller, K.M.; Huh, W.K. Human papillomavirus vaccination: Ongoing challenges and future directions. Gynecol. Oncol. 2020, 156, 498-502. [CrossRef]

4. Szymonowicz, K.A.; Chen, J. Biological and clinical aspects of HPV-related cancers. Cancer Biol. Med. 2020, 17, 864-878. [CrossRef]

5. Brianti, P.; De Flammineis, E.; Mercuri, S.R. Review of HPV-related diseases and cancers. New Microbiol. 2017, 40, 80-85.

6. Centers for Disease Control and Prevention. Human Papillomavirus (HPV). Reasons to Get HPV Vaccine. Available online: https:/ / www.cdc.gov/hpv/parents/vaccine/six-reasons.html\#: \{\}:text=HPV\%20vaccination\%20is\%20cancer\%20prevention, attendance $\% 20$ for $\% 20$ a $\% 20$ baseball\%20game (accessed on 30 September 2021).

7. Paavonen, J.; Naud, P.; Salmerón, J.; Wheeler, C.M.; Chow, S.-N.; Apter, D.; Kitchener, H.; Castellsague, X.; Teixeira, J.C.; Skinner, S.R.; et al. Efficacy of human papillomavirus (HPV)-16/18 AS04-adjuvanted vaccine against cervical infection and precancer caused by oncogenic HPV types (PATRICIA): Final analysis of a double-blind, randomised study in young women. Lancet 2009, 374, 301-314. [CrossRef]

8. Kjaer, S.K.; Sigurdsson, K.; Iversen, O.E.; Hernandez-Avila, M.; Wheeler, C.M.; Perez, G.; Brown, D.R.; Koutsky, L.A.; Tay, E.H.; García, P.; et al. A pooled analysis of continued prophylactic efficacy of quadrivalent human papillomavirus (Types 6/11/16/18) vaccine against high-grade cervical and external genital lesions. Cancer Prev. Res. 2009, 2, 868-878. [CrossRef]

9. Brotherton, J.M.; Fridman, M.; May, C.L.; Chappell, G.; Saville, A.M.; Gertig, D.M. Early effect of the HPV vaccination programme on cervical abnormalities in Victoria, Australia: An ecological study. Lancet 2011, 377, 2085-2092. [CrossRef]

10. Markowitz, L.E.; Hariri, S.; Lin, C.; Dunne, E.F.; Steinau, M.; McQuillan, G.; Unger, E.R. Reduction in human papillomavirus (HPV) prevalence among young women following HPV vaccine introduction in the United States, national health and nutrition examination surveys. 2003-2010. J. Infect. Dis. 2013, 208, 385-393. [CrossRef]

11. Tabrizi, S.N.; Brotherton, J.M.; Kaldor, J.M.; Skinner, S.R.; Liu, B.; Bateson, D.; McNamee, K.; Garefalakis, M.; Phillips, S.; Cummins, E.; et al. Assessment of herd immunity and cross-protection after a human papillomavirus vaccination programme in Australia: A repeat cross-sectional study. Lancet Infect. Dis. 2014, 14, 958-966. [CrossRef]

12. Pollock, K.G.; Kavanagh, K.; Potts, A.; Love, J.; Cuschieri, K.; Cubie, H.; Robertson, C.; Cruickshank, M.; Palmer, T.J.; Nicoll, S.; et al. Reduction of low- and high-grade cervical abnormalities associated with high uptake of the HPV bivalent vaccine in Scotland. Br. J. Cancer 2014, 111, 1824-1830. [CrossRef]

13. Garland, S.M.; Kjaer, S.K.; Muñoz, N.; Block, S.L.; Brown, D.R.; DiNubile, M.J.; Lindsay, B.R.; Kuter, B.J.; Perez, G.; DominiakFelden, G.; et al. Impact and effectiveness of the quadrivalent human papillomavirus vaccine: A systematic review of 10 years of real-world experience. Clin. Infect. Dis. 2016, 63, 519-527. [CrossRef]

14. Baldur-Felskov, B.; Dehlendorff, C.; Munk, C.; Kjaer, S.K. Early impact of human papillomavirus vaccination on cervical neoplasia-Nationwide follow-up of young Danish women. J. Natl. Cancer. Inst. 2014, 106, djt460. [CrossRef]

15. Oliver, S.E.; Unger, E.R.; Lewis, R.; McDaniel, D.; Gargano, J.W.; Steinau, M.; Markowitz, L.E. Prevalence of human papillomavirus among females after vaccine introduction-national health and nutrition examination survey, United States, 2003-2014. J. Infect. Dis. 2017, 216, 594-603. [CrossRef]

16. Luostarinen, T.; Apter, D.; Dillner, J.; Eriksson, T.; Harjula, K.; Natunen, K.; Paavonen, J.; Pukkala, E.; Lehtinen, M. Vaccination protects against invasive HPV-associated cancers. Int. J. Cancer 2018, 142, 2186-2187. [CrossRef]

17. Lei, J.; Ploner, A.; Elfström, K.M.; Wang, J.; Roth, A.; Fang, F.; Sundström, K.; Dillner, J.; Sparén, P. HPV vaccination and the risk of invasive cervical cancer. New Engl. J. Med. 2020, 383, 1340-1348. [CrossRef]

18. Kjaer, S.K.; Dehlendorff, C.; Belmonte, F.; Baandrup, L. Real-world effectiveness of human papillomavirus vaccination against cervical cancer. J. Natl. Cancer Inst. 2021, 113, 1329-1335. [CrossRef]

19. Falcaro, M.; Castañon, A.; Ndlela, B.; Checchi, M.; Soldan, K.; Lopez-Bernal, J.; Elliss-Brookes, L.; Sasieni, P. The effects of the national HPV vaccination programme in England, UK, on cervical cancer and grade 3 cervical intraepithelial neoplasia incidence: A register-based observational study. Lancet 2021, 398, 2084-2092. [CrossRef]

20. WHOEa. Human papillomavirus vaccines: WHO position paper, May 2017-Recommendations. Vaccine 2017, 35, 5753-5755. [CrossRef]

21. WHO Immunization, Vaccines and Biologicals. Available online: https://www.who.int/teams/immunization-vaccines-andbiologicals (accessed on 20 August 2021). 
22. Schiller, J.T.; Castellsagué, X.; Garland, S.M. A review of clinical trials of human papillomavirus prophylactic vaccines. Vaccine 2012, 30, F123-F138. [CrossRef]

23. De Vincenzo, R.; Conte, C.; Ricci, C.; Scambia, G.; Capelli, G. Long-term efficacy and safety of human papillomavirus vaccination Int. J. Women's Health 2014, 6, 999-1010. [CrossRef]

24. Jacot-Guillarmod, M.; Pasquier, J.; Greub, G.; Bongiovanni, M.; Achtari, C.; Sahli, R. Impact of HPV vaccination with Gardasil ${ }^{\circledR}$ in Switzerland. BMC Infect. Dis. 2017, 17, 790. [CrossRef] [PubMed]

25. GlaxoSmithKline Biologicals. Cervarix. Available online: https://gskpro.com/content/dam/global/hcpportal/ja_JP/productsinfo/cervarix/cervarix.pdf (accessed on 31 August 2021).

26. GlaxoSmithKline Biologicals. Gardasil. Available online: https://pins.japic.or.jp/pdf/newPINS/00059715.pdf (accessed on 31 August 2021).

27. GlaxoSmithKline Biologicals. Gardasil9. Available online: https://www.msdconnect.jp/static/mcijapan/images/pi_silgard9 _injinsr.pdf (accessed on 31 August 2021).

28. Harper, D.M.; Franco, E.L.; Wheeler, C.; Ferris, D.G.; Jenkins, D.; Schuind, A.; Zahaf, T.; Innis, B.; Naud, P.; De Carvalho, N.S.; et al. Efficacy of a bivalent L1 virus-like particle vaccine in prevention of infection with human papillomavirus types 16 and 18 in young women: A randomised controlled trial. Lancet 2004, 364, 1757-1765. [CrossRef]

29. Schwarz, T.F.; Spaczynski, M.; Schneider, A.; Wysocki, J.; Galaj, A.; Perona, P.; Poncelet, S.; Zahaf, T.; Hardt, K.; Descamps, D.; et al. Immunogenicity and tolerability of an HPV-16/18 AS04-adjuvanted prophylactic cervical cancer vaccine in women aged 15-55 years. Vaccine 2009, 27, 581-587. [CrossRef]

30. Schwarz, T.F.; Spaczynski, M.; Schneider, A.; Wysocki, J.; Galaj, A.; Schulze, K.; Poncelet, S.M.; Catteau, G.; Thomas, F.; Descamps, D. Persistence of immune response to HPV-16/18 AS04-adjuvanted cervical cancer vaccine in women aged 15-55 years. Hum. Vaccin. 2011, 7, 958-965. [CrossRef]

31. GlaxoSmithKline Vaccine HPV-007 Study Group. Sustained efficacy and immunogenicity of the human papillomavirus (HPV)16/18 AS04-adjuvanted vaccine: Analysis of a randomised placebo-controlled trial up to 6.4 years. Lancet 2009, 374, $1975-1985$. [CrossRef]

32. Verity, R.; Okell, L.C.; Dorigatti, I.; Winskill, P.; Whittaker, C.; Imai, N.; Cuomo-Dannenburg, G.; Thompson, H.; Walker, P.; Fu, H.; et al. Efficacy, safety, and immunogenicity of the human papillomavirus 16/18 AS04-adjuvanted vaccine in women older than 25 years: 7-year follow-up of the phase 3, double-blind, randomised controlled VIVIANE study. Lancet Infect. Dis. 2016, 16, 1154-1168. [CrossRef]

33. Roteli-Martins, C.M.; Naud, P.; De Borba, P.; Teixeira, J.C.; De Carvalho, N.S.; Zahaf, T.; Sanchez, N.; Geeraerts, B.; Descamps, D. Sustained immunogenicity and efficacy of the HPV-16/18 AS04-adjuvanted vaccine: Up to 8.4 years of follow-up. Hum. Vaccines Immunother. 2012, 8, 390-397. [CrossRef]

34. Naud, P.S.; Roteli-Martins, C.M.; De Carvalho, N.S.; Teixeira, J.C.; de Borba, P.C.; Sanchez, N.; Zahaf, T.; Catteau, G.; Geeraerts, B.; Descamps, D. Sustained efficacy, immunogenicity, and safety of the HPV-16/18 AS04-adjuvanted vaccine: Final analysis of a long-term follow-up study up to 9.4 years post-vaccination. Hum. Vaccines Immunother. 2014, 10, 2147-2162. [CrossRef]

35. Schwarz, T.F.; Galaj, A.; Spaczynski, M.; Wysocki, J.; Kaufmann, A.M.; Poncelet, S.; Suryakiran, P.V.; Folschweiller, N.; Thomas, F.; Lin, L.; et al. Ten-year immune persistence and safety of the HPV-16/18 AS04-adjuvanted vaccine in females vaccinated at 15-55 years of age. Cancer Med. 2017, 6, 2723-2731. [CrossRef]

36. Porras, C.; Tsang, S.H.; Herrero, R.; Guillén, D.; Darragh, T.M.; Stoler, M.H.; Hildesheim, A.; Wagner, S.; Boland, J.; Lowy, D.R.; et al. Efficacy of the bivalent HPV vaccine against HPV 16/18-associated precancer: Long-term follow-up results from the Costa Rica vaccine trial. Lancet Oncol. 2020, 21, 1643-1652. [CrossRef]

37. Petäjä, T.; Keränen, H.; Karppa, T.; Kawa, A.; Lantela, S.; Siitari-Mattila, M.; Levänen, H.; Tocklin, T.; Godeaux, O.; Lehtinen, M.; et al. Immunogenicity and safety of human papillomavirus (HPV)-16/18 AS04-adjuvanted vaccine in healthy boys aged 10-18 years. J. Adolesc. Health 2009, 44, 33-40. [CrossRef] [PubMed]

38. Kurosawa, M.; Sekine, M.; Yamaguchi, M.; Kudo, R.; Hanley, S.; Hara, M.; Adachi, S.; Ueda, Y.; Miyagi, E.; Ikeda, S.; et al. Long-term effectiveness of HPV vaccination against HPV infection in young Japanese women: Real-world data. Cancer Sci. 2022. [CrossRef] [PubMed]

39. Garland, S.M.; Hernandez-Avila, M.; Wheeler, C.M.; Perez, G.; Harper, D.M.; Leodolter, S.; Tang, G.W.; Ferris, D.G.; Steben, M.; Bryan, J.; et al. Quadrivalent vaccine against human papillomavirus to prevent anogenital diseases. N. Engl. J. Med. 2007, 356, 1928-1943. [CrossRef] [PubMed]

40. Villa, L.L.; Ault, K.A.; Giuliano, A.R.; Costa, R.L.; Petta, C.A.; Andrade, R.P.; Brown, D.R.; Ferenczy, A.; Harper, D.M.; Koutsky, L.A.; et al. Immunologic responses following administration of a vaccine targeting human papillomavirus Types $6,11,16$, and 18. Vaccine 2006, 24, 5571-5583. [CrossRef]

41. Olsson, S.E.; Villa, L.L.; Costa, R.L.; Petta, C.A.; Andrade, R.P.; Malm, C.; Iversen, O.E.; Høye, J.; Steinwall, M.; Riis-Johannessen, G.; et al. Induction of immune memory following administration of a prophylactic quadrivalent human papillomavirus (HPV) types 6/11/16/18 L1 virus-like particle (VLP) vaccine. Vaccine 2007, 25, 4931-4939. [CrossRef]

42. Luna, J.; Plata, M.; Gonzalez, M.; Correa, A.; Maldonado, I.; Nossa, C.; Radley, D.; Vuocolo, S.; Haupt, R.M.; Saah, A. Long-term follow-up observation of the safety, immunogenicity, and effectiveness of Gardasil ${ }^{\mathrm{TM}}$ in adult women. PLoS ONE 2013, 8, e83431. [CrossRef] 
43. Nygard, M. Long-term effectiveness and immunogenicity of Gardasil ${ }^{\mathrm{TM}}$ in the Nordic countries. In Proceedings of the European Research Organisation On Genital Infection \& Neoplasia Congress, Eurogin, Florence, Italy, 3-6 November 2013.

44. Ferris, D.G.; Samakoses, R.; Block, S.L.; Lazcano-Ponce, E.; Restrepo, J.A.; Mehlsen, J.; Chatterjee, A.; Iversen, O.E.; Joshi, A.; Chu, J.; et al. 4-valent human papillomavirus (4vHPV) vaccine in preadolescents and adolescents after 10 years. Pediatrics 2017, 140. [CrossRef]

45. Kjaer, S.K.; Nygård, M.; Sundström, K.; Dillner, J.; Tryggvadottir, L.; Munk, C.; Berger, S.; Enerly, E.; Hortlund, M.; Ágústsson, Á.I.; et al. Final analysis of a 14-year long-term follow-up study of the effectiveness and immunogenicity of the quadrivalent human papillomavirus vaccine in women from four nordic countries. EClinicalMedicine 2020, 23, 100401. [CrossRef]

46. Palefsky, J.M.; Giuliano, A.R.; Goldstone, S.; Moreira, E.D., Jr.; Aranda, C.; Jessen, H.; Hillman, R.; Ferris, D.; Coutlee, F.; Stoler, M.; et al. HPV vaccine against anal HPV infection and anal intraepithelial neoplasia. N. Engl. J. Med. 2011, 365, 1576-1585. [CrossRef]

47. Goldstone, S.E.; Giuliano, A.R.; Palefsky, J.M.; Lazcano-Ponce, E.; Penny, M.E.; Cabello, R.E.; Moreira, E.D., Jr.; Baraldi, E.; Jessen, H.; Ferenczy, A.; et al. Efficacy, immunogenicity, and safety of a quadrivalent HPV vaccine in men: Results of an open-label, long-term extension of a randomised, placebo-controlled, phase 3 trial. Lancet Infect. Dis. 2021, in press. [CrossRef]

48. Stephen, G. Long-term effectiveness and immunogenicity of quadrivalent HPV vaccine in young men: 10-year end-of study analysis. J. Clin. Oncol. 2018, 36, 1553.

49. Machalek, D.A.; Garland, S.M.; Brotherton, J.; Bateson, D.; McNamee, K.; Stewart, M.; Rachel Skinner, S.; Liu, B.; Cornall, A.M.; Kaldor, J.M.; et al. Very low prevalence of vaccine human papillomavirus types among 18- to 35-year old Australian women 9 years following implementation of vaccination. J. Infect. Dis. 2018, 217, 1590-1600. [CrossRef] [PubMed]

50. Thamsborg, L.H.; Napolitano, G.; Larsen, L.G.; Lynge, E. High-grade cervical lesions after vaccination against human papillomavirus: A Danish cohort study. Acta Obstet. Et. Gynecol. Scand. 2020, 99, 1290-1296. [CrossRef] [PubMed]

51. Shilling, H.; Garland, S.M.; Atchison, S.; Cornall, A.M.; Brotherton, J.; Bateson, D.; McNamee, K.; Kaldor, J.M.; Hocking, J.S.; Chen, M.Y.; et al. Human papillomavirus prevalence and risk factors among Australian women 9-12 years after vaccine program introduction. Vaccine 2021, 39, 4856-4863. [CrossRef] [PubMed]

52. Ruiz-Sternberg, Á.; Moreira, E.D.; Restrepo, J.A.; Lazcano-Ponce, E.; Cabello, R.; Silva, A.; Andrade, R.; Revollo, F.; Uscanga, S.; Victoria, A.; et al. Efficacy, immunogenicity, and safety of a 9-valent human papillomavirus vaccine in Latin American girls, boys, and young women. Papillomavirus. Res. 2018, 5, 63-74. [CrossRef] [PubMed]

53. Huh, W.K.; Joura, E.A.; Giuliano, A.R.; Iversen, O.E.; de Andrade, R.P.; Ault, K.A.; Bartholomew, D.; Cestero, R.M.; Fedrizzi, E.N.; Hirschberg, A.L.; et al. Final efficacy, immunogenicity, and safety analyses of a nine-valent human papillomavirus vaccine in women aged 16-26 years: A randomised, double-blind trial. Lancet 2017, 390, 2143-2159. [CrossRef]

54. Olsson, S.E.; Restrepo, J.A.; Reina, J.C.; Pitisuttithum, P.; Ulied, A.; Varman, M.; Van Damme, P.; Moreira, E.D., Jr.; Ferris, D.; Block, S.; et al. Long-term immunogenicity, effectiveness, and safety of nine-valent human papillomavirus vaccine in girls and boys 9 to 15 years of age: Interim analysis after 8 years of follow-up. Papillomavirus Res. 2020, 10, 100203. [CrossRef]

55. Kjaer, S.K.; Nygård, M.; Sundström, K.; Munk, C.; Berger, S.; Dzabic, M.; Fridrich, K.E.; Waldstrøm, M.; Sørbye, S.W.; Bautista, O.; et al. Long-term effectiveness of the nine-valent human papillomavirus vaccine in Scandinavian women: Interim analysis after 8 years of follow-up. Hum. Vaccin. Immunother. 2021, 17, 943-949. [CrossRef]

56. Schwarz, T.F.; Spaczynski, M.; Schneider, A.; Wysocki, J.; Galaj, A.; Schulze, K. Persistence of immune response 7 years after administration of the HPV-16/18 as04-adjuvanted vaccine to women aged 15-55 years. In Proceedings of the Asia-Oceania Research Organization in Genital Infection and Neoplasia-2011 Interim Conference (AOGIN), Bali, Indonesia, 17-19 March 2011.

57. Pedersen, C.; Petaja, T.; Strauss, G.; Rumke, H.C.; Poder, A.; Richardus, J.H.; Spiessens, B.; Descamps, D.; Hardt, K.; Lehtinen, M.; et al. Immunization of early adolescent females with human papillomavirus type 16 and $18 \mathrm{~L} 1$ virus-like particle vaccine containing AS04 adjuvant. J. Adolesc. Health 2007, 40, 564-571. [CrossRef]

58. Castellsagué, X.; Muñoz, N.; Pitisuttithum, P.; Ferris, D.; Monsonego, J.; Ault, K.; Luna, J.; Myers, E.; Mallary, S.; Bautista, O.M.; et al. End-of-study safety, immunogenicity, and efficacy of quadrivalent HPV (types $6,11,16,18$ ) recombinant vaccine in adult women 24-45 years of age. Br. J. Cancer 2011, 105, 28-37. [CrossRef]

59. Giuliano, A.R.; Palefsky, J.M.; Goldstone, S.; Moreira, E.D., Jr.; Penny, M.E.; Aranda, C.; Vardas, E.; Moi, H.; Jessen, H.; Hillman, R.; et al. Efficacy of quadrivalent HPV vaccine against HPV Infection and disease in males. N. Engl. J. Med. 2011, 364, 401-411. [CrossRef] [PubMed]

60. Goldstone, S.E.; Jessen, H.; Palefsky, J.M.; Giuliano, A.R.; Moreira, E.D., Jr.; Vardas, E.; Aranda, C.; Hillman, R.J.; Ferris, D.G.; Coutlee, F.; et al. Quadrivalent HPV vaccine efficacy against disease related to vaccine and non-vaccine HPV types in males. Vaccine 2013, 31, 3849-3855. [CrossRef]

61. Joura, E.A.; Giuliano, A.R.; Iversen, O.E.; Bouchard, C.; Mao, C.; Mehlsen, J.; Moreira, E.D., Jr.; Ngan, Y.; Petersen, L.K.; LazcanoPonce, E.; et al. A 9-valent HPV vaccine against infection and intraepithelial neoplasia in women. N. Engl. J. Med. 2015, 372, 711-723. [CrossRef] [PubMed]

62. Van Damme, P.; Olsson, S.E.; Block, S.; Castellsague, X.; Gray, G.E.; Herrera, T.; Huang, L.M.; Kim, D.S.; Pitisuttithum, P.; Chen, J.; et al. Immunogenicity and safety of a 9-Valent HPV vaccine. Pediatrics 2015, 136, e28-e39. [CrossRef]

63. Luxembourg, A.; Moreira, E.D., Jr.; Samakoses, R.; Kim, K.H.; Sun, X.; Maansson, R.; Moeller, E.; Christiano, S.; Chen, J. Phase III, randomized controlled trial in girls 9-15 years old to evaluate lot consistency of a novel nine-valent human papillomavirus L1 virus-like particle vaccine. Hum. Vaccin. Immunother. 2015, 11, 1306-1312. [CrossRef] 
64. Konno, R.; Yoshikawa, H.; Okutani, M.; Quint, W.V.; Suryakiran, P.; Lin, L.; Struyf, F. Efficacy of the human papillomavirus (HPV)-16/18 AS04-adjuvanted vaccine against cervical intraepithelial neoplasia and cervical infection in young Japanese women. Hum. Vaccin. Immunother. 2014, 10, 1781-1794. [CrossRef]

65. Guevara, A.; Cabello, R.; Woelber, L.; Moreira, E.D., Jr.; Joura, E.; Reich, O.; Shields, C.; Ellison, M.C.; Joshi, A.; Luxembourg, A.; et al. Antibody persistence and evidence of immune memory at 5years following administration of the 9-valent HPV vaccine. Vaccine 2017, 35, 5050-5057. [CrossRef] 